\title{
PENGEMBANGAN MEDIA NERACA LENGAN UNTUK MEMFASILITASI KEMAMPUAN BERPIKIR LOGIS ANAK USIA DINI
}

\author{
Development of ArmBalanceMedia to Facilitate Logical Thinking Ability in \\ Early Children
}

\author{
Revi Lisdiani ${ }^{1}$ Edi Hendri Mulyana ${ }^{2}$ Dindin Abdul Muiz Lidinillah ${ }^{3}$ \\ Universitas Pendidikan Indonesia Kampus Tasikmalaya ${ }^{123}$ \\ Email; revilisdiani@upi.edu1 \\ Email; edihm1225@gmail.com² \\ Email; dindin_a_muiz@upi.edu ${ }^{3}$
}

\begin{abstract}
DOI: $10.21154 /$ xxx.xxx
\begin{tabular}{l|l|l}
\hline Received: 12 August 2021 & Revised: 20 August 2021 & Approved: 22 August 2021
\end{tabular}

Abstract: This research is motivated by the problems in the field regarding the limited availability of learning media in facilitating early childhood logical thinking skills, especially recognizing differences in objects based on the size of the object's weight. The importance of the ability to think logically from an early age to prepare children to live their daily lives is inseparable from logical thinking. The purpose of this study is to develop learning media to facilitate early childhood analytical thinking skills. The method used in this research is the development method with the Educational Design Research (EDR) model of the McKenney and Reeves model, which has three stages of research: analysis and exploration, design and construction, and evaluation and reflection. Data collection techniques used in this study were interviews, observation, questionnaires, and expert validation. The products that have been developed are then validated by media experts, material experts, and educational experts and then revised by researchers according to the validator's suggestions. Products that have been declared eligible to be tested based on the results of expert validation then tried twice on a limited basis on group B children in TK PGRI Karangmekar. The results of this study indicate that the developed media, namely balance scale media to facilitate early childhood logical thinking skills, is suitable for use in learning according to the results of expert validation, teacher responses, and student's ability to use balance scale media in learning in a limited trial.
\end{abstract}

\section{Keywoards: Balance Scale Media; Early Childhood Education; Logical Thinking}

Abstrak: Penelitian ini dilatarbelakangi oleh adanya permasalahan yang terdapat di lapangan mengenai ketersediaan media pembelajaran yang terbatas dalam memfasilitasi kemampuan berpikir logis anak usia dini khususnya yaitu mengenal perbedaan benda berdasarkan ukuran berat benda. Pentingnya kemampuan berpikir logis sejak usia dini untuk mempersiapkan anak dalam menjalani kehidupan sehari-sehari yang tidak terlepas dari proses berpikir secara logis. Tujuan dari penelitian ini adalah mengembangkan media pembelajaran untuk memfasilitasi kemampuan berpikir logis anak usia dini. Metode yang digunakan dalam penelitian ini adalah metode pengembangan dengan desain Educational Design Research (EDR) model McKenney dan Reeves yang memiliki tiga tahapan penelitian, yaitu analisis dan eksplorasi, desain dan konstruksi, dan evaluasi dan refleksi. Teknik pengumpulan data yang dilakukan pada penelitian ini adalah wawancara, 
Pengembangan Media Neraca Lengan untuk Memfasilitasi Kemampuan Berpikir Logis Anak Usia Dini

observasi, angket, dan validasi ahli. Produk yang telah dikembangkan selanjutnya divalidasi oleh ahli media, ahli materi, dan ahli pedagogik kemudian direvisi oleh peneliti sesuai saran validator. Produk yang telah dinyatakan layak untuk diuji cobakan berdasarkan hasil validasi ahli, selanjutnya diuji cobakan sebanyak dua kali secara terbatas pada anak kelompok B di TK PGRI Karangmekar. Hasil penelitian ini menunjukkan bahwa media yang dikembangkan yakni media neraca lengan untuk memfasilitasi kemampuan berpikir logis anak usia dini layak digunakan dalam pembelajaran sesuai dengan hasil dari validasi ahli, respon guru, dan kemampuan siswa selama menggunakan media neraca lengan dalam pembelajaran pada uji coba terbatas.

Kata Kunci: Media Neraca Lengan, Pendidikan Anak Usia Dini; Berpikir Logis. 


\section{PENDAHULUAN}

Anak usia dini adalah anak yang baru lahir hingga berusia enam tahun yang memiliki karakteristik berbeda dan mempunyai keunikannya masing-masing. Anak usia dini memiliki hak untuk mendapatkan pendidikan. Pendidikan merupakan hal yang mendasar dan berkelanjutan untuk membantu anak dalam proses pertumbuhan serta perkembangannya. Hal tersebut sejalan dengan Undang-undang Nomor 23 Tahun 2002 tentang Perlindungan Anak Bab III Pasal 9 ayat 1 bahwa "setiap anak berhak memperoleh pendidikan dan pengajaran dalam rangka pengembangan pribadinya dan tingkat kecerdasannya sesuai dengan minat dan bakatnya". Dalam proses memenuhi hak pendidikan tersebut diperlukan suatu upaya yang disebut dengan pendidikan anak usia dini.

Berdasarkan Undang-undang Nomor 20 Tahun 2003 tentang Sistem Pendidikan Nasional Pasal 1 ayat 14 pendidikan anak usia dini ialah "suatu upaya pembinaan yang ditujukan kepada anak sejak lahir sampai dengan usia enam tahun yang dilakukan melalui pemberian rangsangan pendidikan untuk membantu pertumbuhan dan perkembangan jasmani dan rohani agar anak memiliki kesiapan dalam memasuki pendidikan lebih lanjut". Dikarenakan anak usia dini berada pada masa peka atau periode sensitif yaitu masa dimana anak mudah menerima stimulus-stimulus dari lingkungannya. 1 Maka stimulasi atau rangsangan pendidikan sangat penting dalam upaya mengembangkan kemampuan anak secara optimal.

Pemberian rangsangan pendidikan dapat dilakukan berdasarkan karakteristik dan tahapan perkembangan anak. Terdapat enam aspek perkembangan anak usia dini yang memerlukan rangsangan pendidikan, diantaranya yaitu nilai agama dan moral, fisik-motorik, bahasa, kognitif, sosial emosional, dan seni. Dalam penelitian ini, aspek perkembangan yang akan diberikan stimulus pendidikan ialah aspek perkembangan kognitif.

Menurut Puspitasari perkembangan kognitif merupakan aspek perkembangan dasar anak yang bertujuan untuk mengembangkan kemampuan berpikir anak dalam kemampuan logis matematis, pengetahuan tentang ruang dan waktu, kemampuan mengelompokkan, dan mempersiapkan kemampuan berpikir secara teliti. ${ }^{2}$ Kemampuan kognitif ialah kemampuan anak untuk berpikir kompleks serta melakukan penalaran dan pemecahan masalah, berkembangnya kemampuan kognitif ini akan mempermudah anak menguasai pengetahuan umum yang lebih luas, sehingga ia dapat berfungsi secara wajar dalam kehidupan masyarakat sehari-

1 Sujiono. (2016). Konsep Dasar Pendidikan Anak Usia Dini. Jakarta: PT Indeks.

2 Hanifah, D. (2019). Pengaruh Kemampuan Berpikir Logis Matematis pada Anak Usia Dini Dengan Menggunakan Media Pembelajaran Lotto Di Kelompok B. Jurnal Ceria, 2(6). 
hari ${ }^{3}$ Yusuf. Dalam Peraturan Menteri Pendidikan dan Kebudayaan Republik Indonesia Nomor 137 Tahun 2014 tentang Standar Nasional PAUD terdapat standar tingkat pencapaian perkembangan anak dalam aspek kognitif yang terbagi menjadi tiga bagian, yaitu belajar dan pemecahan masalah, berpikir logis, dan berpikir simbolik.

Pada penelitian ini, komponen kognitif yang dikaji ialah berpikir logis. Berpikir logis sangat diperlukan disetiap aspek kehidupan sehari-hari, misalnya dalam mengambil keputusan, menarik kesimpulan, dan memecahkan masalah. Menurut Edward untuk kesejahteraan dunia di masa depan, diperlukan orang-orang yang dapat berpikir dengan baik. ${ }^{4}$ Berpikir logis merupakan cara berpikir yang runtut, masuk akal, dan berdasarkan fakta-fakta objektif tertentu. ${ }^{5}$ Berpikir logis adalah suatu proses menalar tentang suatu objek dengan cara menghubungkan serangkaian pendapat untuk sampai pada sebuah kesimpulan menurut aturan-aturan logika. ${ }^{6}$ Salah satu aturan logika yang digunakan untuk mendapatkan pemikiran logis ialah harus memenuhi komponen dasar berpikir logis, diantaranya yaitu pengertian, keputusan, dan penalaran. Menurut Suminah memebrikan definisi berpikir logis adalah memahami tentang perbandingan, pengelompokkan, pola, berinisiatif, berencana, dan mengenal sebab akibat. ${ }^{7}$

Dalam Peraturan Menteri Pendidikan dan Kebudayaan Republik Indonesia Nomor 137 Tahun 2014 tentang Standar Nasional PAUD terdapat standar tingkat pencapaian perkembangan anak usia lima sampai dengan enam tahun dalam lingkup perkembangan kognitif yaitu berpikir logis, diantaranya ialah mengenal perbedaan berdasarkan ukuran: "lebih dari"; "kurang dari"; "paling/ter; 2) menunjukkan inisiatif dalam memilih tema permainan; 3) menyusun perencanaan kegiatan yang akan dilakukan; 4) mengenal sebab-akibat tentang lingkungannya; 5) mengklasifikasikan benda yang lebih banyak ke dalam kelompok yang sama atau kelompok yang sejenis, atau kelompok berpasangan lebih dari dua variasi; 7) mengenal pola ABCD-ABCD; dan 8) mengurutkan benda berdasarkan ukuran dari paling kecil ke paling besar atau sebaliknya. Pada penelitian ini peneliti memfokuskan pada mengenal perbedaan benda berdasarkan ukuran berat dan ringan, serta mengenal sebab-akibat. Dalam memenuhi standar tingkat pencapaian perkembangan anak tersebut, diperlukan media pembelajaran sebagai alat untuk menstimulus kemampuan berpikir logis anak.

${ }^{3}$ Khadijah. (2016). Pengembangan Kognitif Anak Usia Dini. Medan: Perdana Publishing.

${ }^{4}$ Dwi, H. (2017). Melatih Keterampilan Berpikir Anak Usia Dini Melalui Penerapan Metode Montessori. Jurnal Audi, 1(1), 7-14

${ }^{5}$ Octaria, D. (2017). Pendidikan Matematika Universitas Pgri. 181-194.

${ }^{6}$ Rohman, A., D. (2014). Epistemologi dan Logika. Yogyakarta: Aswaja Pressindo.hapi

7 Dista, F. N. (2019). Penerapan Pendekatan Saintifik dalam Mengembangkan Berpikir Logis Anak Usia 5-6 Tahun di RA Takrimah Tungkop Aceh Besar. Al-Athfal Jurnal Pendidikan Anak, 5(2). 217-236. 
Media pembelajaran merupakan salah satu komponen penting dalam proses pembelajaran. Media pembelajaran ialah segala sesuatu yang dapat menyampaikan atau menyalurkan pesan dari suatu sumber secara terencana, sehingga terjadi lingkungan belajar yang kondusif dimana penerimanya dapat melakukan proses belajar secara efisien dan efektif. 8 Media pembelajaran memiliki peran untuk memperjelas penyajian pesan dan mengurangi verbalitas, mengatasi keterbatasan ruang, waktu, dan daya indera manusia, serta meningkatkan motivasi belajar siswa. ${ }^{9}$

Berdasarkan studi literatur penelitian relevan yang dilakukan Hanifah dan Alam (2019) memperoleh hasil bahwa terdapat pengaruh dalam meningkatkan kemampuan berpikir logis-matematis pada anak usia dini dengan menggunakan media pembelajaran lotto di Kelompok B. ${ }^{10}$ Penelitian relevan selanjutnya dilakukan Eri Ardika memperoleh hasil bahwa APE papan alur sangat layak dan praktis digunakan terhadap kemampuan berpikir logis anak usia 5-6 tahun. ${ }^{11}$ Selain itu, terdapat penelitian yang dilakukan Nurul Insyiah Hamid (2013) yang memperoleh hasil bahwa penggunaan media timbangan buatan sangat tepat untuk meningkatkan kemampuan pengenalan ukuran berat pada anak kelompok B TK Pembina Putra. ${ }^{12}$ Dalam penelitian tersebut, media timbangan yang digunakan ialah mainan yang dijual atau tersedia di pasaran.

Merujuk pada hasil penelitian sebelumnya, peneliti berinovasi mengembangkan media pembelajaran yang dapat memfasilitasi atau menstimulus kemampuan berpikir logis anak dalam mengenal konsep berat-tingan, mengenal perbedaan benda berdasarkan ukuran berat-ringan, dan mengenal sebab akibat, yaitu dengan mengembangkan media neraca lengan. Dalam penelitian sebelumnya, untuk meningkatkan atau memfasilitasi kemampuan berpikir logis diantaranya menggunakan media lotto atau papan alur. Sedangkan dalam penelitian ini, media yang digunakan ialah media neraca lengan yaitu media berbentuk timbangan yang terbuat dari susunan pipa yang dihubungkan menggunakan sambungan pipa dan baut.

Selain studi literatur, peneliti juga melakukan studi lapangan dengan menggunakan pedoman wawancara untuk memperoleh data dari guru kelompok B TK PGRI Karangmekar. Di TK PGRI Karangmekar tidak tersedia media pembelajaran yang dapat memfasilitasi kemampuan berpikir logis, khususnya

8 Asyhar, R. (2012). Kreatif Mengembangkan Media Pembelajaran. Jakarta:Referensi Jakarta.

${ }^{9}$ Guslinda. (2018). Media Pembelajaran Anak Usia Dini. Surabaya: Jakad Publishing.

${ }^{10}$ Hanifah, D. (2019). Pengaruh Kemampuan Berpikir Logis Matematis pada Anak Usia Dini Dengan Menggunakan Media Pembelajaran Lotto Di Kelompok B. Jurnal Ceria, 2(6).

11 Ardika, E. (2021). Pengembangan APE Papan Alur terhadap Kemampuan Berpikir Logis Anak Usia 5-6 tahun. (Skripsi). Universitas Islam Negeri Ar-Raniry Darussalam, Banda Aceh.

${ }^{12}$ Insyiah Hamid, N. (2013). Penggunaan Media Timbangan Dalam Meningkatkan Pengenalan Konsep Ukuran Berat Benda Pada Anak Kelompok B Tk Pembina Putra Surabaya. PAUD Teratai, 2(1). 
dalam mengenal konsep berat ringan dan membandingkan benda berdasarkan ukuran berat ringan (Guru B, komunikasi pribadi, 26 Juni 2021).

Berdasarkan hasil studi literatur dan hasil studi lapangan, peneliti tertarik untuk melakukan penelitian mengenai media pembelajaran yang dapat dirumuskan dalam judul "Pengembangan Media Neraca Lengan untuk Memfasilitasi Kemampuan Berpikir Logis Anak Usia Dini".

\section{PEMBAHASAN}

\section{Kebutuhan Pengembangan Media Neraca Lengan untuk Memfasilitasi Kemampuan Berpikir Logis Anak Usia Dini}

Dasar kebutuhan pengembangan media neraca lengan untuk memfasilitasi kemampuan berpikir logis anak usia dini merujuk pada tuntutan kebutuhan di lapangan dan teori. Dalam Peraturan Menteri Pendidikan dan Kebudayaan Nomor 137 (2014) terdapat standar tingkat pencapaian perkembangan anak pada lingkup perkembangan kognitif pada komponen berpikir logis, yaitu mengenal perbedaan berdasarkan ukuran (lebih dari, kurang dari, dan paling/ter). ${ }^{13}$ Hal tersebut sejalan dengan hasil temuan di lapangan bahwa kemampuan berpikir logis di TK PGRI Karangmekar pada kelompok B selalu disampaikan pada proses pembelajaran, seperti membandingkan benda berdasarkan ukuran panjang-pendek, besar-kecil, banyak-sedikit, tinggi-rendah, dan mengelompokkan benda berdasarkan warna dan ukuran. Dalam pembelajaran, terkadang guru menggunakan media pembelajaran untuk menyampaikan materi pembelajaran kepada anak. Media pembelajaran yang sering digunakan untuk memfasilitasi kemampuan berpikir logis anak diantaranya balok, bola, dan benda tiruan, yang penggunaannya yaitu secara langsung membandingkan ukuran benda tersebut, misalnya balok yang panjang dengan balok yang pendek. Pengembangan kemampuan dasar yang berkaitan dengan ukuran diperoleh dari pengalaman anak pada waktu ia berinteraksi dengan membandingkan, mengklasifikasikan, dan menyusun atau mengurutkan benda. ${ }^{14}$

Konsep pengukuran pada anak usia dini merupakan salah satu kemampuan kognitif yang harus dicapai, antara lain mengenal perbedaan benda berdasarkan ukurannya, mengukur benda dengan menggunakan satuan tidak baku, dan mengelompokan benda berdasarkan ukurannya ${ }^{15}$. Menurut PP PAUD dan DIKMAS Jawa Barat (2016) pada tahap pengukuran awal, anak tidak menggunakan alat ukur,

${ }_{13}$ Pendidikan, K., \& Kebudayaan, D. A. N. (2014). Menteri Pendidikan dan Kebudayaan Republik Indonesia Nomor 137 Tahun 2014 Tentang Kurikulum 2013 Pendidikan Anak Usia Dini.

${ }^{14}$ Fatdianti, R., \& Rianto, E. (2016). Pengaruh Metode Proyek terhadap Kemampuan Mengenal Konsep Ukuran Anak Kelompok B. Jurnal Mahasiswa Teknologi Pendidikan, 5(1), 16.

${ }^{15}$ Hapipah, H., Komariah., \& S. (2016). Meningkatkan Kemampuan Kognitif Anak Usia Dini Dalam Mengenal Konsep Pengukuran Dengan Menggunakan Media Piramida Pintar. Jurnal PGPAUD Kampus Cibiru, 3(3), 1-11. 
tetapi mengenalkan konsep panjang-pendek, besar-kecil, tinggi-rendah, beratringan, banyak-sedikit. Tahap berikutnya, anak diajak menggunakan alat ukur tidak baku, dan pada tahap lebih tinggi anak menggunakan alat ukur baku seperti menggunakan penggaris, timbangan, dan meteran. Anak akan mahir dalam pengukuran baku, jika disediakan kegiatan pengukuran tidak baku sesering mungkin. ${ }^{16}$ Manfaat media pembelajaran dalam proses pembelajaran yaitu bahan pembelajaran akan lebih jelas maknanya sehingga dapat lebih dipahami oleh siswa dan memungkinkan siswa untuk menguasai dan mencapai tujuan pembelajaran. ${ }^{17}$ Namun di TK PGRI Karangmekar tidak tersedia media pembelajaran yang dapat memfasilitasi kemampuan berpikir logis, khususnya dalam mengenal konsep berat ringan dan membandingkan benda berdasarkan ukuran berat ringan, sehingga peneliti mengembangkan media neraca lengan untuk memfasilitasi kemampuan berpikir logis anak pada konsep pengukuran.

Rancangan Pengembangan Media Neraca Lengan untuk Memfasilitasi Kemampuan Berpikir Logis Anak Usia Dini

Peneliti membuat desain pengembangan produk berupa media neraca lengan untuk memfasilitasi kemampuan berpikir logis anak usia dini, dan buku panduan penggunaan media neraca lengan untuk dapat dijadikan solusi dan menambah variasi dalam penerapan media pembelajaran di TK kelompok B. Berikut ini tabel rancangan Pengembangan Media Neraca Lengan.

Tabel 1.1Desain Prototipe Media Neraca Lengan untuk Memfasilitasi Kemampuan Berpikir Logis Anak Usia Dini

\begin{tabular}{|c|c|c|}
\hline No. & Gambar & Keterangan \\
\hline 1. & & $\begin{array}{l}\text { Alas Neraca } \\
\theta \text { Sambungan pipa tee stuck } \\
\square \quad \text { Pipa } 1 / 2 \text { inci panjang } 5 \mathrm{~cm} \\
\square \quad \text { Sambungan pipa knee elbow }\end{array}$ \\
\hline 2. & & $\begin{array}{l}\text { Pilar Neraca } \\
\qquad \begin{array}{l}\text { Pipa } 1 / 2 \text { inci panjang } 30 \mathrm{~cm} \\
\epsilon_{0} \text { Baut } 1 / 4 \text { inci panjang } 8 \mathrm{~cm} \\
\text { Mur }\end{array}\end{array}$ \\
\hline
\end{tabular}

16 PP PAUD dan DIKMAS Jawa Barat. (2016). Model Pengenalan Matematika Melalui Permainan Kreatif Bagi Anak Usia 5-6 tahun. PP PAUD dan Dikmas, hlm. 19.

17 Arsyad, A. (2013). Arsyad, A. (2013). Media Pembelajaran. Rajagrafindo Persada. 


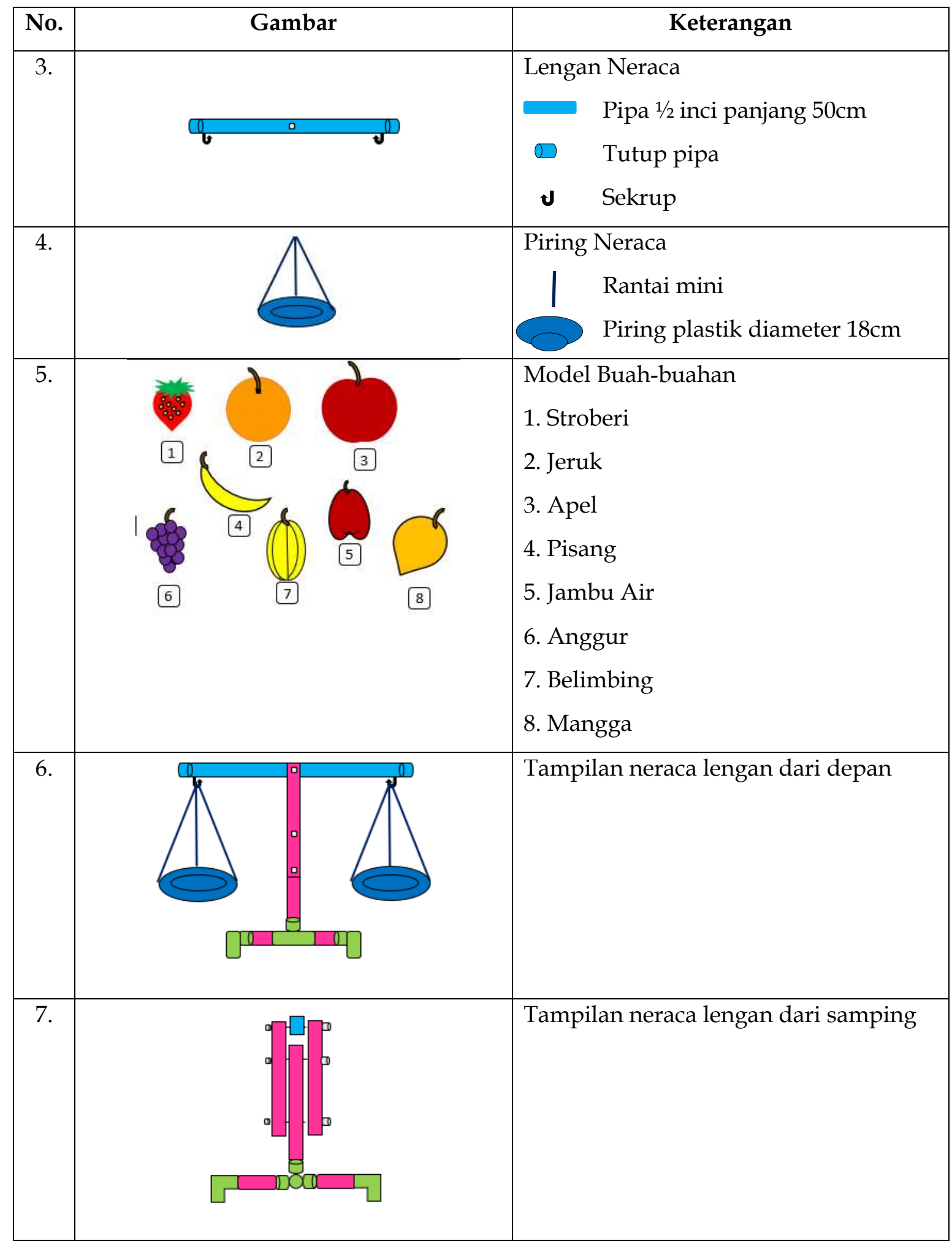

Desain pengembangan media neraca lengan ini merujuk pada hubungan antara tuntutan teoretis dan tuntutan kebutuhan lapangan. Langkah awal yang dilakukan peneliti dalam mengembangkan produk media neraca lengan yaitu menyusun rancangan produk yang di dalamnya terdapat landasan pengembangan media, tujuan media, komponen media, alat dan bahan pembuatan media, cara 
pembuatan media, cara penggunaan media, skenario pembelajaran menggunakan media neraca lengan, dan desain prototipe media neraca lengan, kemudian membuat prototipe awal dan buku panduan penggunaan media neraca lengan. Rancangan produk dan prototipe awal di validasi oleh ahli bidang media, ahli bidang materi, dan ahli pedagogik. Hasil dari validasi ahli tersebut menyatakan bahwa media neraca lengan ini layak untuk diujicobakan di PAUD setelah diperbaiki sesuai saran dari validator ahli.

\section{Implementasi Pengembangan Media Neraca Lengan untuk Memfasilitasi Kemampuan Berpikir Logis Anak Usia Dini}

Produk media neraca lengan yang telah dikembangkan selanjutnya dilakukan uji coba untuk mengetahui penggunaan media neraca lengan pada pembelajaran, hasil belajar siswa setelah menggunakan media neraca lengan, dan keterpakaian media oleh guru. Uji coba terbatas dilaksanakan di TK PGRI Karangmekar yang dilakukan sebanyak dua kali kepada siswa dan guru kelompok B. Peneliti melakukan uji coba terbatas pada waktu yang berbeda dan anak yang berbeda.

Kegiatan uji coba terbatas tahap 1 dilaksanakan pada hari Senin, 2 Agustus 2021 pada kelompok B2 TK PGRI Karangmekar dengan melibatkan empat orang anak. Hasil uji coba yang telah dilaksanakan menunjukkan bahwa media neraca lengan untuk memfasilitasi kemampuan berpikir logis anak usia dini dapat digunakan oleh guru dan siswa. Media neraca lengan mendapat respon yang baik dari guru dan siswa, juga terdapat peningkatan kemampuan berpikir logis anak kelompok B TK PGRI Karangmekar setelah menggunakan media neraca lengan. Pada tahap ini tidak ada yang perlu diperbaiki.

Kegiatan uji coba terbatas tahap 2 dilaksanakan pada hari Kamis, 5 Agustus 2021 pada kelompok B1 TK PGRI Karangmekar dengan melibatkan enam orang anak. Hasil uji coba yang telah dilaksanakan menunjukkan bahwa media neraca lengan untuk memfasilitasi kemampuan berpikir logis anak usia dini dapat digunakan oleh guru dan siswa. Media neraca lengan mendapat respon yang baik dari guru dan siswa, juga terdapat peningkatan kemampuan berpikir logis anak kelompok B TK PGRI Karangmekar setelah menggunakan media neraca lengan.

Berdasarkan hasil validasi produk dan uji coba terbatas yang telah dilakukan dapat disimpulkan bahwa media neraca lengan untuk memfasilitasi kemampuan berpikir logis anak usia dini sudah dikategorikan sebagai media yang layak untuk digunakan dalam proses pembelajaran sesuai dengan respon positif yang ditunjukkan oleh guru dan siswa, dan didasarkan pada hasil observasi kemampuan berpikir logis anak dalam menggunakan media neraca, serta hasil angket respon guru terhadap penggunaan media neraca lengan.

\section{KESIMPULAN}

Berdasarkan hasil dari pengembangan media neraca lengan untuk memfasilitasi kemampuan berpikir logis anak usia dini bahwa kebutuhan dasar 
untuk media neraca lengan berdasarkan hasil studi lapangan di TK PGRI Karangmekar ternyata tidak ada media untuk memfasilitasi kemampuan berpikir logis dalam aspek mengenal konsep berat ringan, dan mengenal perbandingan berdasarkan ukuran berat ringan, sedangkan hasil studi literatur bahwa pentingnya aspek perkembangan kognitif dalam lingkup berpikir logis untuk mengenalkan anak agar mampu mengenal perbandingan, dan mengenal sebab akibat di dalam kehidupan sehari-hari, serta pentingnya media pembelajaran untuk tercapainya tujuan pembelajaran. Oleh karena itu, perlu adanya pengembangan media agar anak dapat melaksanakan pembelajaran secara optimal.

Pembuatan produk pengembangan media neraca lengan ini berdasarkan hasil analisis permasalahan yang didapatkan dari studi pendahuluan yang selanjutnya dirancang menjadi rancangan umum media neraca lengan. Rancangan umum dan produk yang sudah divalidasi kelayakannya oleh validator ahli selanjutnya diuji cobakan di PAUD. Implementasi atau uji coba produk dalam kegiatan pembelajaran dilaksanakan secara terbatas sebanyak dua tahap di TK PGRI Karangmekar. Berdasarkan uji coba yang sudah dilaksanakan, membuktikan bahwa produk hasil pengembangan berupa media neraca lengan dapat dijadikan media yang layak bagi anak usia lima sampai dengan enam tahun. Produk media neraca lengan ini dapat menjawab permasalahan yang terjadi di lapangan, yaitu untuk memfasilitasi kemampuan berpikir logis anak usia dini.

Secara keseluruhan, peneliti dapat menyimpulkan bahwa media neraca lengan yang dikembangkan layak dan dapat digunakan sebagai media yang dapat memfasilitasi aspek perkembangan kognitif, khususnya berpikir logis anak usia lima sampai dengan enam tahun. Media neraca lengan yang dikembangkan dapat menambah variasi media pembelajaran bagi guru, sedangkan bagi anak media neraca lengan ini dapat mengenalkan konsep berat ringan, mengenalkan konsep pengukuran dengan alat ukur tidak baku, dan dapat meningkatkan motivasi belajar anak.

\section{REFERENSI}

Ardika, Eri. 2021. "Pengembangan APE Papan Alur Terhadap Kemampuan Berpikir Logis Anak Usia 5-6 Tahun." (Skripsi). Universitas Islam Negeri Ar-Raniry Darussalam, Banda Aceh.

Arsyad, A. 2013. Arsyad, A. (2013). Media Pembelajaran. Jakarta: Rajagrafindo Persada. Asyhar, R. 2012. Kreatif Mengembangkan Media Pembelajaran. Jakarta:Referensi Jakarta.

Dista, Fitrah. 2019. "Penerapan Pendekatan Saintifik Dalam Mengembangkan Berpikir Logis Anak Usia 5-6 Tahun Di RA Takrimah Tungkop Aceh Besar" 5: 217-36.

Dwi, Hastuti. 2017. Melatih Keterampilan Berpikir Anak Usia Dini Melalui 
Penerapan Metode Montessori. Jurnal Audi 1 (1): 7-14.

Fatdianti, R., \& Rianto, E. 2016. "Pengaruh Metode Proyek Terhadap Kemampuan Mengenal Konsep Ukuran Anak Kelompok B." Jurnal Mahasiswa Teknologi Pendidikan 5 (1): 1-6.

Guslinda. 2018. Media Pembelajaran Anak Usia Dini. Surabaya: Jakad Publishing. Hanifah, Dkk. 2019. "Pengaruh Kemampuan Berpikir Logis Matematis Pada Anak Usia Dini Dengan Menggunakan Media Pembelajaran Lotto Di Kelompok B." Jurnal Ceria 2 (6).

Hapipah, H., Komariah., \& Susilowati. 2016. "Meningkatkan Kemampuan Kognitif

Anak Usia Dini Dalam Mengenal Konsep Pengukuran Dengan Menggunakan

Media Piramida Pintar." Jurnal PGPAUD Kampus Cibiru 3 (3): 1-11.

Khadijah. 2016. Pengembangan Kognitif Anak Usia Dini. Medan: Perdana Publishing.

Model Pengenalan Matematika Melalui Permainan Kreatif Bagi Anak Usia 5-6 Tahun. 2016. Bandung: PP PAUD dan Dikmas.

Octaria, Dina. 2017. Pendidikan Matematika Universitas PGRI, no. 2004: 181-94.

Peraturan Menteri Pendidikan dan Kebudayaan Republik Indonesia Nomor 137 Tahun 2014 tentang Standar Nasional PAUD

Peraturan Menteri Pendidikan dan Kebudayaan Republik Indonesia Nomor 146 Tahun 2014 tentang Kurikulum 2013 PAUD

Rohman, A., Dkk. 2014. Epistemologi Dan Logika. Yogyakarta: Aswaja Pressindo. Sujiono. 2016. Konsep Dasar Pendidikan Anak Usia Dini. Jakarta: PT Indeks. 